\title{
Right of the Citizen and Evaluation of Health Services: Theoretical-Practical Approaches ${ }^{1}$
}

\author{
Nalú Pereira da Costa Kerber ${ }^{2}$ \\ Ana Lúcia Cardoso Kirchhof \\ Marta Regina Cezar-Vaz ${ }^{4}$ \\ Rosemary Silva da Silveira ${ }^{5}$
}

This study was carried out at a Family Medical Unit in a city in the south of Brazil, aiming at analyzing how the evaluation process takes place in a Brazilian public health unit, specifically considering a home care service. Data were collected through observation of the work process and interviews with workers, managers and users, between March and June 2006. The subjects were asked about the means applied to evaluate the home care service. No work is done to identify problems and reorient actions taken, evaluating the practices and measuring the impact of service and program actions on the population's health status.

Descriptors: Right to Health; Home Nursing; Health Services Evaluation.

\footnotetext{
${ }^{1}$ Paper extracted from Doctoral Dissertation "A atenção domiciliária e direito à saúde: análise de uma experiência na rede pública de saúde no Brasil", presented to Universidade Federal de Santa Catarina, SC, Brazil. Supported by CNPq process \# 401933/05-9.

${ }^{2}$ RN, Ph.D. in Nursing, Professor, Escola de Enfermagem, Universidade Federal do Rio Grande, RS, Brazil. E-mail: nalu@vetorial.net.

${ }^{3}$ RN, Ph.D. in Philosophy of Health, Retired Professor, Universidade Federal de Santa Catarina, SC, Brazil. Visiting Researcher, Universidade Federal do Paraná, PR, Brazil. E-mail: kirchhof@terra.com.br.

${ }^{4}$ RN, Ph.D. in Philosophy of Health, Professor, Escola de Enfermagem, Universidade Federal do Rio Grande, RS, Brazil. E-mail: cezarvaz@vetorial.net.

${ }^{5}$ RN, Ph.D. in Nursing, Professor, Escola de Enfermagem, Universidade Federal do Rio Grande, RS, Brazil. E-mail: anacarol@mikrus.com.br.
}

Corresponding Author:

Nalú Pereira da Costa Kerber

Universidade Federal do Rio Grande. Escola de Enfermagem.

Rua General Osório, S/N

Centro

CEP: 96201-900 Rio Grande, SP, Brasil

E-mail: nalu@vetorial.net 


\title{
Direito do cidadão e avaliação nos serviços de saúde: aproximações teórico-práticas
}

Este estudo foi desenvolvido em unidade de medicina de família de um município do Sul do país, com o objetivo de analisar como vem se desenvolvendo o processo avaliativo no interior de um serviço público de saúde brasileiro, na especificidade serviço de atenção domiciliária. Procedeu-se à coleta de dados por meio da observação do processo de trabalho e de entrevistas com trabalhadores, gestores e usuários, no período de março a junho de 2006. Os sujeitos foram questionados acerca das formas utilizadas para a realização da avaliação do serviço de atenção domiciliária. Percebeu-se que não há um trabalho voltado à identificação de problemas e reorientação de ações desenvolvidas, avaliando as práticas e mensurando o impacto das ações implementadas pelos serviços e programas sobre o estado de saúde da população.

Descritores: Direito à Saúde; Assistência Domiciliar; Avaliação de Serviços de Saúde.

\section{Derecho del ciudadano y evaluación en los servicios de salud: aproximaciones teórico-prácticas}

\begin{abstract}
Este estudio fue desarrollado en una Unidad de Medicina de Familia de un municipio del sur de Brasil, con el objetivo de analizar como viene desarrollándose el proceso de evaluación en el interior de un servicio público de salud brasileño, específicamente en un servicio de atención a domicilio. Se procedió a la recolección de datos por medio de la observación del proceso de trabajo y de entrevistas con trabajadores, administradores y usuarios, en el período de marzo a junio de 2006. Los sujetos fueron cuestionados acerca de las formas utilizadas para realizar la evaluación del servicio de atención domiciliaria. Se percibió que no existía un trabajo dirigido a identificar problemas y reorientar acciones desarrolladas, evaluando las prácticas y midiendo el impacto de las acciones implementadas por los servicios y programas sobre el estado de salud de la población.

Descriptores: Derecho a la Salud; Atención Domiciliaria de Salud; Evaluación de los Servicios de Salud.
\end{abstract}

\section{Introduction}

In the historical construction and permanence process of human beings, health is a fundamental aspects that grants them conditions to exist, live and develop, combining different factors, such as housing, food, leisure, work, among others. The right of any and all citizens to the ways to achieve these conditions is legitimated in the Brazilian Constitution of 1988.

The universal rights of human beings include the right to health, which means that "Any and all Brazilians should build and enjoy economic and social public policies that reduce health risks and problems. This right equally means universal (for all) and equanimous (with fair equality) access to health promotion, protection and recovery services and actions (comprehensive care)"(1).
The universal acknowledgement of the right to health and social rights started in the Second World War, when various movements appeared in defense of human rights, as well as codes that questioned the power of the State towards its citizens, particularly the fight for rights to health(2).

In Brazil, the right to health means that the State should guarantee dignified living conditions and universal and equalitarian access to health promotion, protection and recovery actions and services, at all of its levels, to all inhabitants within the national territory, leading to the full development of human beings in their individuality.

As a civil right, health services and actions should be provided in a decentralized way and submitted to 
social control. Thus, the Unified Health System (SUS) proposal is considered to be the best doctrine to construct citizenship. "Citizenship presupposes equality of rights, implies a reciprocal relation of respect for rights and duties between citizens and the state, with a view to materializing the subject's desires through sociopolitical discussions; the participation of stakeholders in this space can mean the redistribution of rights to all $(\ldots)^{\prime \prime(2)}$

Citizenship in health has been exercised through the establishment of Health Councils, in which society lives the State/Population relation and constructs its concept of right to health. One of the forms to exercise this control is through the assessment of health services. Service assessment and the right to health are considered interdependent elements. The population's participation in health services serves to better adequate the services to the population's needs, which is not always easy to achieve. Moreover, it is known that, in different assessment models and measures, service users are an important component to assess the interventions and interaction with the context in the observed products(3).

Acknowledging that assessment processes are still incipient in Brazil, little incorporated into practices and more prescriptive, bureaucratic and punitive than supportive for planning and management, the Ministry of Health (MS) launched the document Assessment in Primary Health Care $^{(4)}$, in line with the international movement to institutionalize assessment, put in practice in different countries like the United States, England, Canada and France.

That is one way of directing services towards the accomplishment of assessment processes, considered fundamental in any and all health services. How can one know whether health needs are being attended to? How can one guarantee that the type of work is necessary for the population within the coverage area? Through the continuous assessment of service delivery, with a view to the availability of parameters to maintain or transform the work. This service evaluation aspect is considered an important component in the validation of clients' rights, as it is a way to objectify them in daily institutional reality.

Reflecting on the importance for citizens, both health system users and services, to consider health as an unalienable right for all in their daily lives and for health services to be subject to continuous assessment, in this study, it is analyzed how this evaluation process has been developed in a Brazilian public health service, specifically looking at a home care service.

\section{Method}

A qualitative, interpretative study was carried out, in which the researcher attempts to understand and explain aspects of social life that go beyond the study subjects $^{(5)}$.

The place of study was a Family Medicine Unit located in a complex public health service organization in a state capital in Southern Brazil, which has been offering home care as part of its work process for 25 years. The sample was composed according to groups of workers involved in home care (physicians, nurses, nursing technicians and auxiliaries and residents in Medicine, Nursing and Psychology), service managers and users. The first group totaled 22 workers. The second group comprised the institution's coordinator, the head of the health unit and three community representatives in the Local Health Council. The third group included both patients and caregivers, using the data saturation criterion to close off the sample, so that seven users participated.

Data were collected through direct observation of the home care work process following workers at the unit and during home visits, between March and June 2006, and also through individual interviews with home care program workers, managers and users.

This study was carried out after approval was obtained from the Research Ethics Committee of the institution the health unit under analysis belongs to, according to Opinion No. 105/05. To preserve the interviewed subjects' anonymity, they were identified with the first letter of their category ( $N$ for nurses; $P$ for physicians; R for residents, followed by the letter corresponding to the specific residency, whether in Nursing, Medicine or Psychology; M for managers; and $F$ for family members/users) followed by the number indicating the order in which the interviews were held.

Considering home care as a historical and dialectical substrate of health work, reflections were carried out against this background.

\section{Results}

When attempting to understand work and worker assessment processes and their development, users unanimously agreed that they had never participated in any assessment process and had not even been asked about the work the home care team has developed. One of the families manifested itself positively in this respect, inferring that this process may not happen because there is no need as, according to the family, the importance and relevance of accomplishing this type of 
work practice seems clear: we are always so satisfied. But with this goal of assessing whether we are satisfied, if we have any complaint, no. And we really do not have any complaint, just praise (F3).

For the workers, service assessment gains the meaning focused on during weekly home care case discussion meetings: We have weekly meetings for home care patients. During the meetings assessment is done, we see when someone new enters the program, we see who has a patient, who hasn't, who's going to enter, how visits are going, difficulties, if any change is needed, that's done during these meetings (N1). On Mondays, we always have that meeting when we get news on the bedridden and try to solve it in the team, discuss the case. When the case is difficult, involves family problems, caregivers, intrigues among them, we discuss it in the team (P2).

Different participants displayed this understanding and manifested that no evaluation process is developed in home care: We don't have any evaluation. Now we are starting the basic thing of knowing how many visits we are doing, because I couldn't even see that before. No matter how many reports, setting a program there, we did so many trainings, so many things, we've already done it manually, it never works. In fact, the program has never been assessed as it should be. Besides the fact that we have to do it manually, I can only know if the visit happened, who did it (N8). There is no indicator, for example, that home care decreases hospitalizations, or that it decreases mortality, that's something that still needs to be constructed (P1).

One of the managers alerts to the process that is starting at this service, involving the standardization and assessment of home care, mentioning that, through this mobilization, the health units will get involved, have a guideline at their disposal and may feel more motivated to assess the work process and, hence, to have data that can help to improve care quality: I think that several things will get better now because, as the institution is thinking of an assessment policy, that might be of influence. Having an institutional assessment and professional performance policy, the one that is being issued, it's not just an individual assessment proposal but, like you are assessed, you assess your coordinator. There's team assessment and individual assessment, which influences the team assessment. If you start to have that kind of assessment in home care... (M1).

At the health unit under analysis, no latent concern with this issue exists, to the extent that there are no evaluation processes. There is concern, however, with solving any problems that might have come up during care, or which the users present. According to the research participants, attempts are always made to solve the problems listed: Bring into the big team that something is not working well, that assessment is done (N4). That comes back to us, in the form of complaining about the doctor or complaining that the nurse didn't go or complaining that they are trying to keep a person at home who cannot stay at home (P3).

Mobilization occurs in view of complaints, manifested problems, however, without looking at the work organization, in the sense of seeing and perceiving how it is being developed and analyzing whether the workers' actions and the service range respond to the clients' rights and needs. The testimonies revealed the inexistence of assessments, considering both the workers' individual and the group work process: It does not occur yet, no assessment of the workers exists yet (N3). It happens here in the team. For example, charges appeared that things were kind of relaxed, kind of left aside, nobody knew about anyone, who was whose patients, what he had, what she had. But nobody assesses you, I've never heard anyone say: look, you are developing very well. Until today nobody has come to do that, nobody has assessed me (N7).

The nurses, then, assume the responsibility of assessing home care in the sense of the work organization, focusing on the dynamics of team activities. When understanding the contents expressed in the statements and during the work process, an actual tacit agreement exists that the nurse is the figure responsible for maintaining and controlling that practice. And control exists. In fact, I'm the one who controls that: the number of visits, if people are actually being visited, at what frequency they are being visited. And I control that, charging people who didn't visit and also informing these people at the unit to the referral professional when a visit is requested. Every month, I tell each person if there's any problem (RN1). The nurses control the patients being followed and how long those patients have not been visited (P1).

\section{Discussion}

Although no assessment process exists at the service under analysis, the users manifested their satisfaction with home care. This does not guarantee care quality though, as the users present limited understanding, dictated by what they perceive to be their needs, besides their lack of perspective on potential care and its relation with the community that receives care. Thus, they are already satisfied with the existence of this service within their reach.

Hence, it is questioned as a possible intervening factor for users' assessment on their rights and the care 
they receive whether this positive assessment is related with their vulnerability condition. This is associated with the fear of expressing dissatisfactions and desires, or with their possible lack of knowledge on their rights and issues related to inequalities, such as the population that needs but is not included in this care for example. In the poorest part of the population, it seems that the notion of right is mixed up with "that of a given and a favor", which restricts the possibilities of fighting and claiming rights ${ }^{(6)}$. In very unequal contexts, for certain population segments, the usual difficulty to get care results in low expectations. The mere fact of receiving care can already produce satisfaction, as people do not expect much from public institutions ${ }^{(7)}$. They expect the action that is done instead of the relation between the need and the product, that is, the need is simplified as an accomplished activity, care.

In this perspective, assessing the individual and collective work process seems to be necessary for a better understanding of existing conflicts between the moral actions that can and should be accomplished to protect the users' interests in terms of a fair, equitable and appropriate treatment ${ }^{(8)}$.

The conception of justice as equity proposes that all people have equal rights, such as the right to exercise their freedom and equal opportunities. Social inequalities, however, should be seen in unequal ways, that is, departing from the principle of difference, which proposes maximum benefits for the poorest beings in society ${ }^{(9)}$.

And, regarding the workers, the meaning presented in the testimonies seems to include only direct issues of each home care patient. Assessment is only manifested in the sense of control and case evolution, or even workers' assessment. Assessment focuses on the object/ client/user, more specifically in the action/activity (s)he receives, and not on the work process.

In primary health care services, however, assessment should be used to "define and characterize the community; identify the community's health problems; modify programs to address these problems; monitor the efficacy of program modifications"(10).

Besides representing an opportunity to verify the community's answer to the health service offered in practice and to better adapt the service to the expectations of its target community, "the room for the user's assessment of the health service favors the humanization of the service, exercises acceptance of the other's view and perception and also favors the necessary socio-anthropological analyses for a better contextualization of the health service offered"(11).
Assessment offers "the possibility to create room for reflection about practice, deconstruct current ideas or construct common senses regarding concepts and discourses"(10,12). This connotation exists because assessment can support workers and managers to make more consistent choices regarding the directions of their initiatives.

Service management is starting to reflect on the consolidation of the assessment, in line with governmental policies, which has been trying to gain room in the health system. The MS presents, as one of its premises: "Health assessment is a critical-reflexive process on practices and processes developed in the context of health services. It is a continuous and systematic process whose temporality is defined in function of the context it is established in"(4).

When this type of determination occurs at the level of super-structures, assessment becomes easier, which does not mean that its accomplishment in microstructural spaces is easy, like in the case of this study. As it is at macro-level that the policies and guidelines of work are elaborated, it is at the micro-level that they are developed in a way adapted to their own needs and reality. It becomes easier, because they function as an example and guideline of actions.

It is not easy for workers involved in daily service problems, such as the population's high demands, to manage to establish time at work to structure an assessment logic. That is a task for managers, who should take charge of this process, mobilizing workers to reflect and participate, but based on solid and facilitating instruments to achieve the goals of the assessment that will be performed. It should be admitted that the structures exert an actual force, even if relative, which imposes restrictions on the subjects ${ }^{(13)}$.

Assessment is considered a process that should be structured and accomplished at micro level, by the services; but which should be a process institutionalized at macro level, in the service organization as a whole. When investing in the institutionalization of the assessment, one is decisively contributing to the goal of qualifying health care, promoting the construction of structured and systematic processes, coherent with the principles of the Unified Health System, besides helping services to construct an assessment culture.

The need for assessment to exist at this service is understood, but one of the possible technical obstacles that emerge as an impediment for this process to gain form is the lack of a computer program to facilitate data storage and control. One of the managers affirms 
that they cannot quantify the work performed because no epidemiological indicators have been constructed. "Assessing and monitoring these services' performance is an important need today for proposals to improve care quality"(14).

One of the ways to improve care quality is the workers' performance assessment process. That is a way of monitoring how the work is taking place and a part of the teaching-learning process, which is characteristic of nurses' educative activity and contributes to the improvement of care quality ${ }^{(15)}$.

More than any other health professional, nurses have frequent opportunities to facilitate and manifest their respect for patients' rights. As team leaders, assuming the leadership of patient care, nurses are the main source of personal, intimate and continuous contact with the patients(16). Using this proximity, they can help users to see themselves as co-responsible for care quality, as soon as they assess the care received in the different health services they use. On the other hand, users can stimulate nurses to look at the work processes and produce assessment activities.

Assessing health service development is not only necessary, but also fundamental to achieve the desired care quality. Assessment "should support problem identification and reorientation of developed actions and services, assess the incorporation of new health practices into professionals' routine and measure the impact of service and program actions on the population's health condition"(4)

In this sense, truly and fully achieving the goals of SUS depends on the incorporation of assessment processes into its functional dynamics. "It is only through founded and careful reflection on what one does and how one does it that coverage, problem-solving ability and access can actually be achieved and, what is more important, with effective social control"(17).

Health system managers and health service managers in particular demonstrate their responsibility towards services when they are concerned with its systematic assessment. This concern reveals interest in the quality of these services and the quality of the care delivered there, as health care quality means that "health services are attending to existing or potential health needs in an optimized way, given current knowledge on the distribution, acknowledgement, diagnosis and management of health-related problems and concerns"(10).

Managers need to concretely express concern with these issues, in the form of protocols, assessment programs, epidemiological and methodological instruments that facilitate the workers' accomplishment of this process. Management at the service under analysis started a mobilization movement in this sense, with a view to regulating the health care assessment process in the health services under its responsibility, but still has not managed to develop it in the home care service.

The final highlight in the testimonies regards the nurse's relation with the assessment. These workers are considered and consider themselves responsible for this process. Assessment is perceived as an activity inherent to this worker. This is a reality at all health services, as it is known that nurses' administrative functions include performance assessment of employees in their work group $^{(18)}$.

It is highlighted that the home care context is an ideal stage for assessment processes, inserting users into this process. Without the development of these processes, the users are not included as citizens.

The methods that incorporate the user's perspective are seen as part of a paradigm in which principles related to individual and civil rights are reaffirmed, as expressed in the concepts of humanization and patient rights ${ }^{(7)}$.

\section{Final considerations}

It could be perceived that no work is done to identify problems and reorient actions taken, evaluating the practices and measuring the impact of service and program actions on the population's health status.

Assessing the work process demonstrates concern and accountability, guaranteeing the civil rights of health system users. Guaranteeing the right to health means not only guaranteeing service access, but also guaranteeing the best and most adequate care quality inside these services for the population's needs.

As a research area, assessment has grown inside services, moving beyond the academic context. This is also the case because, without assessment, it is difficult to plan. On the other hand, given the lack of public resources, project funding is requested from international entities, and assessment is one of their requirements. Difficulties remain in the objects that need to be assessed, which are generally complex and require creative and distinguished approaches, favoring criticism and reflection.

Therefore, this is a task that can no longer be delayed, it has to be faced and health care has to be qualified, including contributions from this area, at danger of turning its actions obsolete. 


\section{References}

1. Associação Paulista de Mediicina. SUS: o que você precisa saber sobre o Sistema Único de Saúde, volume 1. São Paulo (SP): Atheneu; 2004.

2. Soares NV, Lunardi VL. Os direitos do cliente como uma questão ética. Rev Bras Enferm. 2002 jan/fev;55(1):64-9.

3. Hartz ZMA, Silva LMV (org). Avaliação em saúde: dos modelos teóricos à prática na avaliação de programas e sistemas de saúde. Salvador: EDUFBA; Rio de Janeiro: Fiocruz; 2005

4. Ministério da Saúde (BR). Secretaria de Atenção à Saúde. Departamento de Atenção Básica. Coordenação de Acompanhamento e Avaliação; Coordenação técnica: Instituto de Saúde Coletiva da Universidade Federal da Bahia e Instituto Materno Infantil Prof. Fernando Figueira, IMIP. Avaliação na Atenção Básica em Saúde: caminhos da institucionalização. Brasília (DF): Ministério da Saúde; 2005.

5. Amezcua M, Toro AG. Los modos de análisis en investigación cualitativa en salud: perspectiva critica y reflexiones en voz alta. Rev Esp Salud Publica 2002 sep/out;76(5):423-36.

6. Vargas LA, Oliveira TFV, Garbois JA. O direito à saúde e ao meio ambiente em tempos de exclusão social. Rev Latino-am Enfermagem [serial on the internet]. 2007 [acesso 23 abril 2009]; 15(especial):850-6. Disponível em: http://www.scielo. br/pdf/rlae/v15nspe/pt_20.pdf.

7. Vaitsman J, Andrade GRB. Satisfação e responsividade: formas de medir a qualidade e a humanização da asistencia à saúde. Cienc Saúde Colet 2005;10(3):599-613.

8. Beauchamp TL, Childress JF. Princípios de ética biomédica. São Paulo (SP): Loyola; 2002.

9. Rawls J. Sobre las libertades. Barcelona (ES): Paidós; 1990.

10. Starfield B. Atenção primária: equilíbrio entre necessidades de saúde, serviços e tecnologia. Brasília (DF): UNESCO, Ministério da Saúde; 2002.
11. Teixeira SA. Avaliação dos usuários sobre o programa de saúde da família em Vitória da Conquista - Bahia - Brasil. In: Fernandes AS, Seclen-Palacin JA, organizadores. Experiências e desafios da atenção básica e saúde familiar: caso Brasil. Brasília (DF): Organização Pan-Americana da Saúde; 2004. p. 77-101. 12. Silva RR, Brandão D. Os quatro elementos da avaliação. 2003 [acesso 17 jan 2007]; Congresso Nacional da Rede Unida. 5. Londrina/PR. 24 a 27 de maio de 2003. Disponível em: www. preval.org/documentos/00816.pdf .

13. Schraiber LB, Nemes MIB. Processo de trabalho e avaliação de serviços de saúde. Cadernos FUNDAP 1996; 19:106-21.

14. Sala A, Nemes MIB, Cohen DD. Metodologia de avaliação do trabalho na atenção primária à saúde. Cad Saúde Pública 1998 out./dez; 14(4):741-51.

15. Balbueno EA, Nozawa MR. Levantamentos dos tipos de repercussões resultantes da avaliação de desempenho em enfermagem hospitalar. Rev. Latino-Am. Enfermagem. 2004; 12(1):58-64.

16. Trevizan MA, Mendes IAC, Lourenço, MR, Shinyashiki GT. Aspectos éticos na ação gerencial do enfermeiro. Rev. LatinoAm. Enfermagem. [seriado na internet]. 2002 [acesso 23 abril 2009]; 10(1):85-9. Disponível em: http://www.scielo.br/scielo. php?script=sci_arttext\&pid=S0104-11692002000100013

17. Camargo KR Junior, Campos SEM, Teixeira MTB, Mascarenhas MTM, Mauad NM, Franco TB. Aspectos metodológicos da avaliação na atenção básica. In: Pinheiro $R$, Mattos $R$, organizadores. Gestão em redes: práticas de avaliação, formação e participação na saúde. Rio de Janeiro (RJ): CEPESC; 2006. p. 223-41.

18. Brahm MMT, Magalhães AMM. Opinião da equipe de enfermagem sobre o processo de avaliação de desempenho. Acta Paul Enferm. 2007;20(4):415-21.

Received: Jun. $22^{\text {th }} 2009$

Accepted: Ago. 25th 2010 